\title{
New geographical record and morphological features of the Indo-Pacific tropical sand goby, Favonigobius reichei (Bleeker, 1854) from Iranian coast of the Makran Sea (Teleostei, Gobiidae)
}

\author{
Reza Sadeghi, ${ }^{1}$ Hamid Reza Esmaeili, ${ }^{1,2}$ Ronald Fricke, ${ }^{3}$ Helen K. Larson ${ }^{4}$
}

1 Ichthyology and Molecular Systematics Research Laboratory, Zoology Section, Department of Biology, College of Sciences, Shiraz University, Shiraz, Iran. 2 Department of Earth and Environmental Sciences, Palaeontology \& Geobiology, Ludwig-Maximilians-University Munich, RichardWagner-Straße 10, D-80333 Munich, Germany. 3 Im Ramstal 76, 97922 Lauda-Königshofen, Germany. 4 Museum \& Art Gallery of the Northern Territory, PO Box 4646, Darwin, NT 0801, Australia.

Corresponding author: Hamid Reza Esmaeili, hresmaeili@shirazu.ac.ir

\begin{abstract}
The Indo-Pacific tropical sand goby, Favonigobius reichei (Bleeker, 1854), is a gobiid fish native to estuarine and marine waters of the coasts of the Indian and the western Pacific Oceans. Four specimens of $F$. reichei were collected from Iranian coast of the Makran Sea during a fish survey in November 2015. The morphological features of these specimens are described and discussed. This is the first record of the species from Iranian waters and is an extension of its known range within the Indian Ocean.
\end{abstract}

Key words

Gobioidei; geographical range; range extension; morphological characteristics.

Academic editor: Arturo Angulo Sibaja | Received 11 August 2017 | Accepted 4 September 2017 | Published 20 October 2017

Citation: Sadeghi R, Esmaeili HR, Fricke R, Larson HK (2017) New geographical record and morphological features of the Indo-Pacific tropical sand goby, Favonigobius reichei (Bleeker, 1854) from Iranian coast of the Makran Sea (Teleostei: Gobiidae). Check List 13 (5): 641-645. https:// doi.org/10.15560/13.5.641

\section{Introduction}

Gobiidae is one of the largest families of vertebrates, belonging to the perciform suborder Gobioidei, with at least 1924 species described in 309 genera (Larson and Hoese in prep); presently 1854 valid species in 5 subfamilies exist according to Eschmeyer et al. (2017). Gobiids inhabit marine, brackish, and freshwater environments in most tropical and subtropical regions of the Indo-Pacific. (Nelson et al. 2016, Froese and Pauly 2017). Members of this family live in diverse and sometimes harsh habitats, including intertidal zones, where few other fish families are well-adapted to live (Larson and Murdy 2001).

They show spectacular variety in morphology, ecol- ogy, and behavior. Despite extensive recent literature on their taxonomy, phylogeny, composition, and importance in coastal water biodiversity, their phylogenetic relationships with many groups of gobioids are not yet stabilized, perhaps due to their small size and lack of immediate economic importance. (Nelson et al. 2016, Agorreta et al. 2013). Gobies are generally benthic and occupy a wide range of habitats, from rivers and mangrove mudflats to coral reefs. They attain a small body size (often less than $50 \mathrm{~mm}$ ). They are distinct with pelvic fins usually wholly or partially joined into a disc and have separate spinous and rayed dorsal fins (Thacker 2012).

Gobiid fishes have been sometimes misidentified in studies conducted in the Persian Gulf and Gulf of 


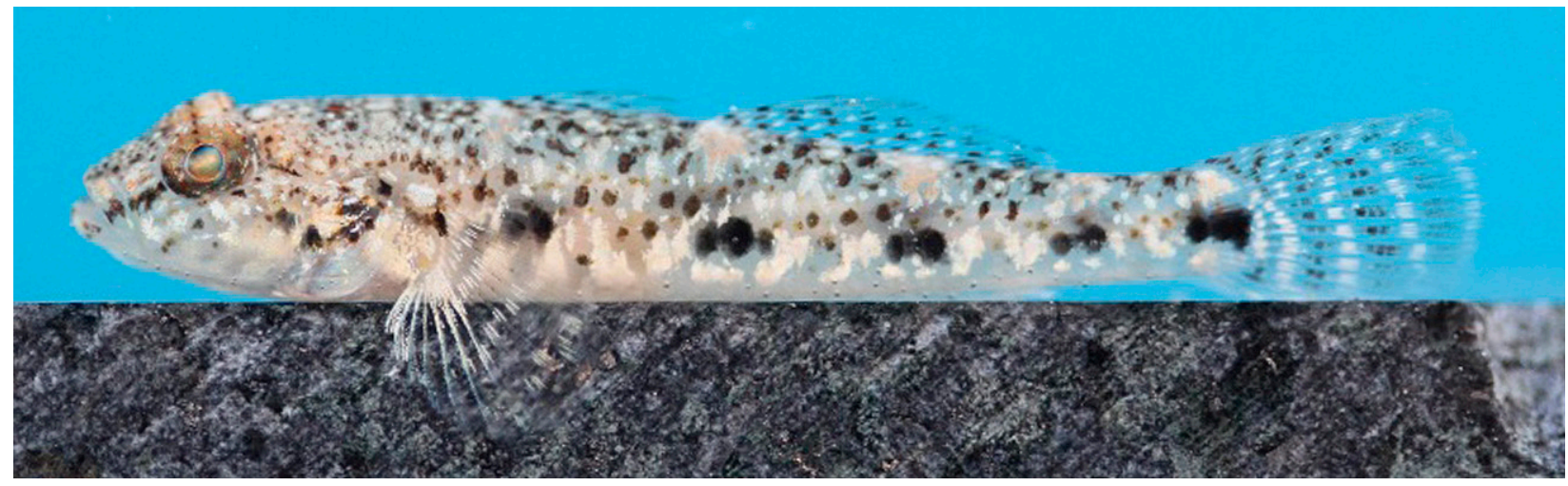

Figure 1. Favonigobius reichei, $29.45 \mathrm{~mm}$ SL collected from coastal area of Gatan village, Makran Sea, Iran.

Oman, probably due to their small size and lack of current literature. One of the earliest studies on the fishes of Iranian waters of the Persian Gulf is that of Blegvad and Loppenthin (1944), in which they reported 12 species of gobiids. Later, Kuronuma and Abe (1972) reported 4 species of this family from the coastal waters of Kuwait. In a field guide to the marine fishes of Kuwaiti waters (Jones 1986), 6 species of Gobiidae were listed from the area, while in Carpenter et al. (1997a), the number of gobiid species was increased to 44 , of which only 14 species were accompanied by schematic figures. Furthermore, Carpenter et al. (1997b) reported 15 species of Gobiidae from the coral reefs of Kuwait. Bishop (2003) reported 26 gobiid species from the southern Persian Gulf and Rahimian and Pehpuri (2006) reported 8 gobiid species from Qeshm Island.

The genus Favonigobius Whitley, 1930 commonly referred to as a "sand goby" currently comprises 9 valid species (Froese and Pauly 2017). According to Larson and Murdy (2001), the genus Favonigobius can be diagnosed by the presence of a large patch of papillae on chin; multiple short irregular rows of papillae on cheek between 2 lowermost longitudinal papillae rows and papillae row directly under eye double; 5 to 6 longitudinal rows of papillae on cheek; first or second dorsal-fin spine may be elongate in mature males; snout short and pointed; no scales on cheek or opercle; whitish to pale yellowish body with fine dark spots and speckles; and dark spots along midside of body smaller than eye.

Favonigobius reichei Bleeker, 1854, commonly referred to as the Indo-Pacific tropical sand goby, is known so far from South Africa west to Ponape (Micronesia) and north to Japan; it has a wide distribution in the Red Sea, Indo-West Pacific, East Africa, South Africa, Seychelles and Mauritius (Mascarenes) east to Marshall Islands and New Guinea, north to southern Japan, and south to northern Australia and New Caledonia. (Larson in press, Kottelat et al. 1993, Fricke 1999, Patzner et al. 2012).

Although $F$. reichei has been reported from coastal areas of Oman (Al-Jufaili et al. 2010), there has been no record of it from the Iranian coast of the Makran Sea (Rahimian and Pehpuri 2006, Ghanbarifardi and Malek 2007). Hence, the main objective of this work is recording $F$. reichei for the first time from the Iranian coast of the Makran Sea and providing its morphological characteristics.

\section{Methods}

Four specimens of F. reichei with total lengths (TL) of 29.5-34.7 $\mathrm{mm}$ and standard lengths (SL) of 23.3-29.5 mm (Fig. 1) were collected from a shallow rocky reef interspersed with sandy coastline of Gatan village, between Sirik and Jask ports, Hormozgan province, Iran, $25^{\circ} 57^{\prime} \mathrm{N}, 057^{\circ} 15^{\prime} \mathrm{E}, 6$ December 2015 , using a hand net (Figs 2-4).

Due to the small sample size and detailed examination for example molecular analysis, after anesthesia, the specimens were fixed in $95 \%$ alcohol and brought to the laboratory. The specimens are deposited in the Zoological Museum of Shiraz University, Collection of Biology Department, Shiraz (ZM-CBSU) under museum numbers of ZM-CBSU M1579, ZM-CBSU M1580, ZM-CBSU M1594, and ZM-CBSU M1595.

Morphometric measurements were taken to the nearest $0.1 \mathrm{~mm}$ using digital calipers. A stereomicroscope was used for the meristic characters. Morphometric characters were expressed as \% standard length (SL) and $\%$ head length (HL). Morphometric methods followed Miller (1988); meristic methods followed Chen and Fang (2006) and Chen and Miller (2008). Meristic abbrevia-

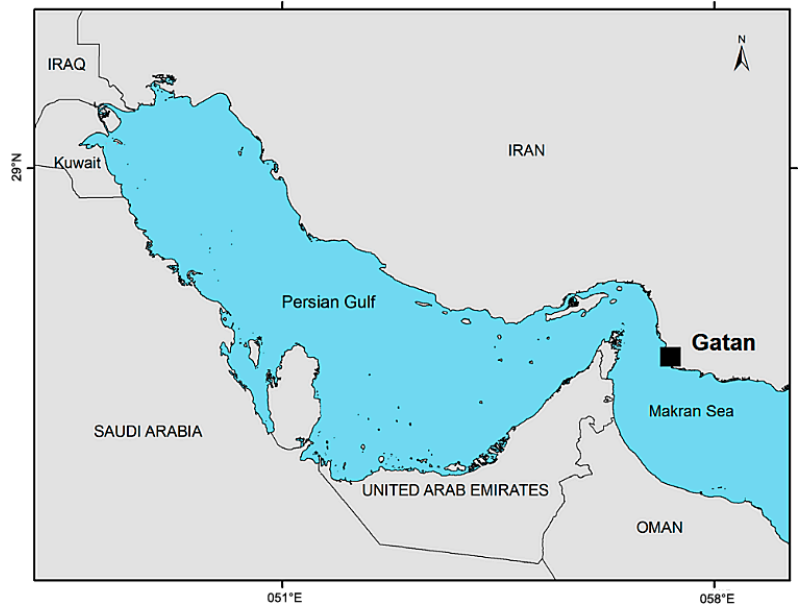

Figure 2. Collection site of $F$. reichei from coastal area of the Makran Sea, Iran $\left(25^{\circ} 57^{\prime} \mathrm{N}, 057^{\circ} 15^{\prime} \mathrm{E}\right)$ 


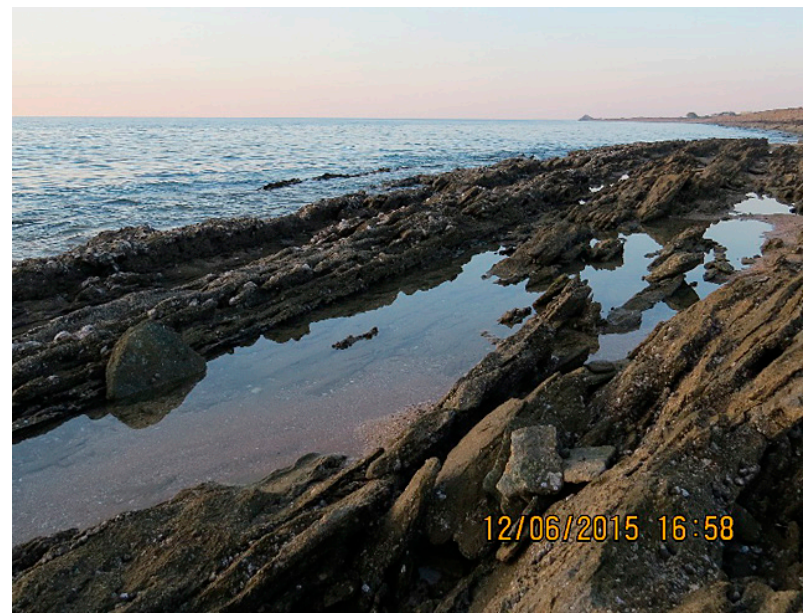

Figure 3. Gatan shore, Hormuzgan Province, Iran; new collection site for F. reichei.

tions are as follows: D1 $=$ First dorsal fin; D2 $=$ Second dorsal fin; $\mathrm{V}=$ Ventral fin; $\mathrm{A}=$ Anal fin; $\mathrm{P}=$ Pectoral fin; PSD $=$ Predorsal scales; LSS $=$ Longitudinal scales series; and TSS $=$ Transverse scales series. Morphometric measurements were made to the nearest $0.1 \mathrm{~mm}$ using caliper.

\section{Results}

We primarily used the key of Larson and Murdy (2001) for the identification of the genus of Favonigobius and subsequently identified the collected individuals as $F$. reichei by analyzing the following morphometric and meristic characters:

Fin ray counts D1: VI; D2: I, 8; A: I, 8; P: 15; PSD: 2; LSS: 29; TSS: 8.

See Figure 1 for general appearance; morphometric data are given in Table 1. Body moderately elongate; head short (27-29\% SL); snout short, steep and pointed; eyes

Table 1. Morphometric characters of 4 specimens of $F$. reichei collected from the Coast of Makran Sea. All values except for total length (TL) and standard length (SL) are proportions.

\begin{tabular}{lccc}
\hline Morphometric measurements & Min. & Max. & Mean \\
\hline Total length (TL, mm) & 29.48 & 34.68 & 31.16 \\
Standard length (SL, mm) & 23.30 & 29.45 & 25.36 \\
Standard length (SL) /TI & 0.78 & 0.85 & 0.81 \\
Head length (HL) /SI & 0.27 & 0.29 & 0.28 \\
Body depth at pelvic origin (BDP) /SI & 0.14 & 0.16 & 0.15 \\
Head width (HW) /SI & 0.17 & 0.21 & 0.19 \\
Pre first dorsal length (Pre-FDL) /SI & 0.33 & 0.37 & 0.36 \\
First dorsal fin base length (FDFL) /SI & 0.06 & 0.09 & 0.07 \\
Second dorsal fin base length (SDFL) /SI & 0.14 & 0.22 & 0.18 \\
First dorsal fin length /SI & 0.16 & 0.18 & 0.17 \\
Second dorsal fin length /SI & 0.27 & 0.36 & 0.30 \\
Pectoral fin length (PcFL) /SI & 0.20 & 0.27 & 0.23 \\
Pelvic fin base depth /SI & 0.07 & 0.11 & 0.09 \\
Pre pelvic length /SI & 0.30 & 0.37 & 0.32 \\
Anal fin base length (AFL) /SI & 0.17 & 0.20 & 0.18 \\
Anal fin length /SI & 0.26 & 0.30 & 0.28 \\
Pre anal fin length (PAL) /SI & 0.54 & 0.58 & 0.56 \\
Caudal peduncle length (CPL) /SI & 0.21 & 0.26 & 0.23 \\
\hline
\end{tabular}

dorso-lateral and not large; interorbital space less than one-eighth eye diameter; anterior nostril tubular, without tentacles, posterior nostril pore-like, near orbit; mouth oblique; jaws equal, posterior angle of lower jaw between anterior edge of orbit and pupil; chin without barbels or transverse fold; teeth in jaws erect and caniniform, in several rows medially, outer row of teeth in both jaws enlarged; pharyngeal teeth caniniform; tongue truncate; caudal fin rounded, usually slightly longer than head; pectoral fins without free rays; pelvic disc complete (united medially), pelvic frenum present and well developed; preopercle without spines; gill rakers $1+8$, and simple on first arch, spinulose on internal and external side of rest in groups 2-4; pre-pelvic scales large and cycloid; belly scales small and cycloid; head, opercle and cheek naked; scales ctenoid except cycloid on breast and pectoral fin base; scale absent on remainder of head; multiple longitudinal head papillae pattern; and single anterior interorbital pore (Fig. 1).

According to genital papilla, all 4 specimens are female. Head and body are whitish to pale yellowish, the upper two-third of body with numerous small brown and black spots and blotches on scales; a mid-lateral row of blackish spots with 4 or 5 slightly enlarged groups of black spots, the first beneath pectoral fin, last spot on caudal peduncle often paired without a vertical bar at caudal base; median fins spotted; paired fins pale; and a short black and oblique streak on side of snout extending from antero-ventral edge of eye to across lips. Basal two-thirds of D1 and D2 and caudal fins with small black spots on a white reticulum (Fig. 1).

Favonigobius reichei is very similar in appearance to F. melanobranchus (Fowler, 1934) (Fig. 5). However, F. reichei is distinguished from $F$. melanobranchus by having 8 or 9 transverse scales rows (vs 7 transverse scales rows) and 1 or 2 predorsal scales (vs 7 predorsal scales in F. melanobranchus). Moreover, F. melanobranchus has black spots on the upper edge of the caudal fin and its membranes at sides of isthmus are black (Fig. 5).

Based on Bogorodsky et al. (2011), the principal colour characters distinguishing these species are the presence of a black spot or oval blotch dorsally on the caudal fin of $P$. melanobranchus (absent in $P$. reichei), and the presence of orange lines on lower part of body of $P$. melanobranchus (absence in P. reichei, though may be indistinct). Underwater photographs of $P$. reichei for comparison may be seen in Senou et al. (2004) and Larson and Lim (2005).

\section{Key to Favonigobius species of the study area}

a Predorsal scales in 7 rows, but scales not reaching eye; males with black spot dorsally on caudal fin and often with black on branchiostegal membranes

\section{F. melanobranchus}

b Predorsal with 1 or 2 scales; males without black spot on upper part of caudal fin and branchiostegal membranes always pale. 


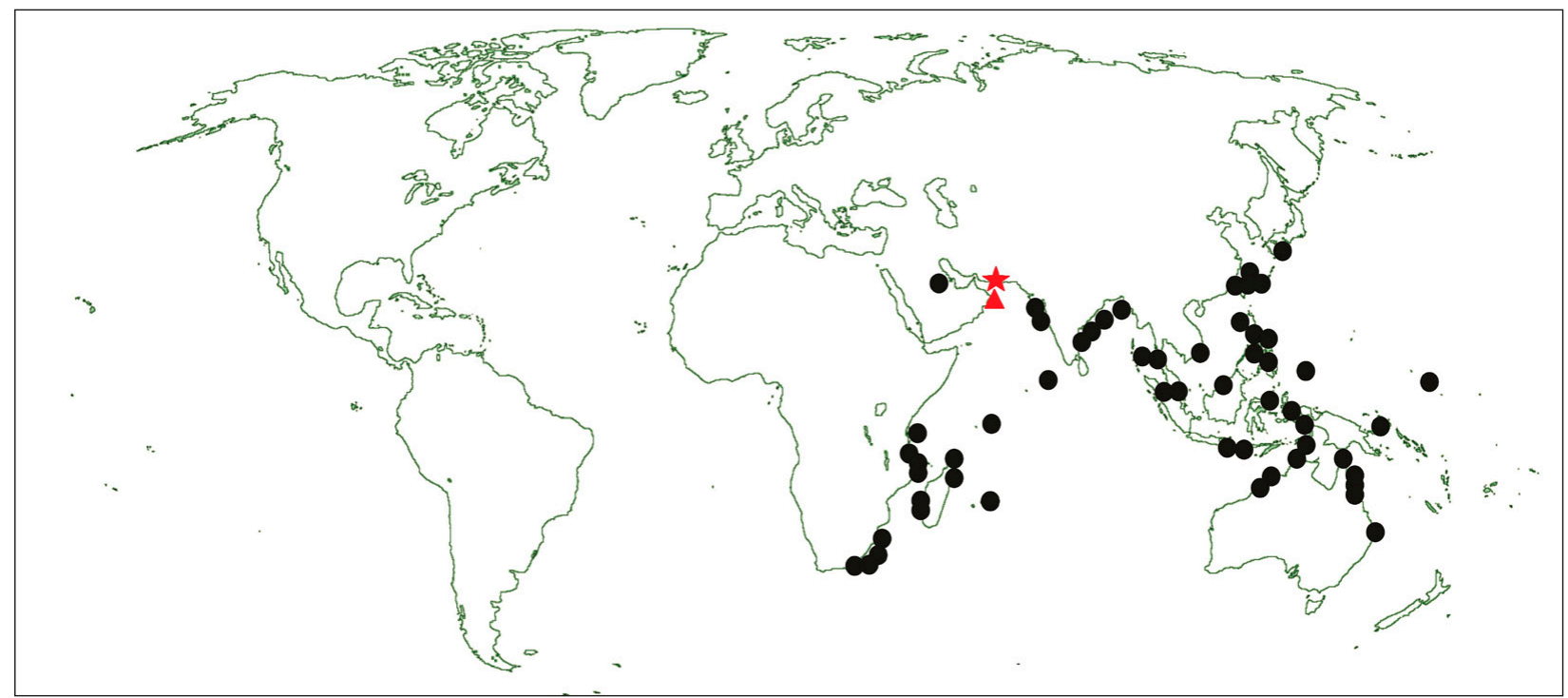

Figure 4. World distribution map of F. reichei, including new record (red star) and previous record from Oman coastal area (red triangle).

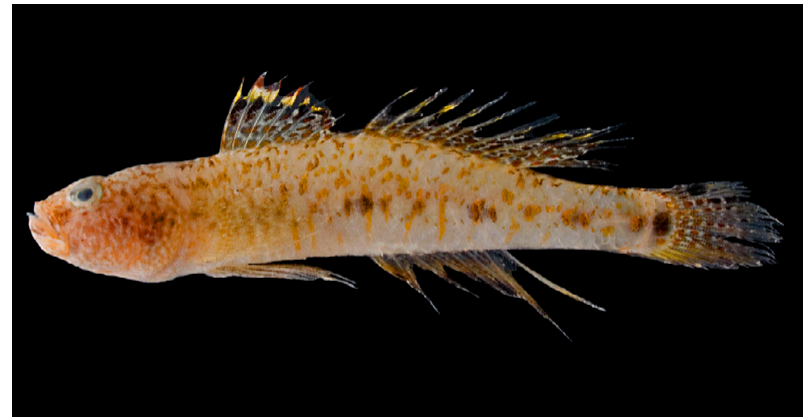

Figure 5. Favonigobius melanobranchus (Fowler, 1934), freshly collected specimen, PMR 2218, male, 45.5 mm SL, Gulf of Suez (Photo S.V. Bogorodsky), (with permission of Bogorodsky, S.V., Kovačić, M. and J.E. Randall).

\section{Discussion}

Favonigobius reichei is a euryhaline fish and has a wide distribution (Fig. 4) in the Red Sea, Persian Gulf, Gulf of Oman, Mozambique, South Africa, Seychelles and Mauritius (Mascarenes) east to New Guinea, north to southern Japan, and south to northeastern Australia (Larson in press, Masuda et al. 1984, Kottelat et al. 1993, Fricke 1999, Patzner et al. 2012). It is found at depths of 0-5 m. This species is found over muddy or sandy bottoms, often in weedy areas of the intertidal zone, and also in mangroves, estuaries, lagoons, and downstream parts of rivers.

Favonigobius reichei is a common Indo-Pacific tropical sand goby inhabiting rocky to sandy bottoms, with at least 143 georeferenced records worldwide in Global Biodiversity Information Facility (GBIF 2017).

The present record is a new addition to the marine fish species list for Iran. The discovery of $F$. reichei in Iranian waters indicates that a suitable habitat for this species occurs along the Iranian coast of the Makran Sea and that additional species of sand goby in the subfamily Gobiinae may be discovered in the future.

\section{Acknowledgements}

We thank H. Mehraban and H. Hashemi for their help and support in the fieldwork. The research work was funded by Shiraz University and was approved by the Ethics Committee of Biology Department (SU- 9330207).

\section{Authors' Contributions}

RS collected the specimens; RS and HRE examined and identified the specimens; and RF and HKL verified the specimens. RS and HRE prepared the figures. All authors prepared, reviewed, finalized, and approved the manuscript.

\section{References}

Al-Jufaili SM, Hermosa G, Al-Shuaily SS, Mujaini AAl (2010) Oman Fish Biodiversity. Journal of King Abdulaziz University, Marine Science 21: 3-51.

Agorreta A, San Mauro D, Schliewen U, Van Tassell JL, Kovačić M, Zardoya R, Rüber L (2013) Molecular phylogenetics of Gobioidei and phylogenetic placement of European gobies. Molecular Phylogenetics and Evolution 69: 619-633.

Bishop JM (2003) History and current checklist of Kuwait's ichthyofauna. Journal of Arid Environments 54: 237-256.

Bleeker P (1854) Nieuwe tientallen diagnostische beschrijvingen van nieuwe of weinig bekende vischsoorten van Sumatra. Natuurkundig Tijdschrift voor Nederlandsch Indië 5 (3): 495-534.

Blegvad H, Loppenthin B (1944) Fishes of the Iranian Gulf, Danish Scientific Investigations in Iran. Einar Munksgaard, Copenhagen, 247 pp.

Bogorodsky SV, Kovačić M, Randall JL (2011) New species and three new records of gobiid fishes from the Red Sea. Cybium 35: 213-222.

Carpenter KE, Krupp F, Jones DA, Zajonz U (1997a) FAO species identification field guide for fishery purposes: living marine resources of Kuwait, Eastern Saudi Arabia, Bahrain, Qatar, and the United Arab Emirates. Food and Agriculture Organization of the United Nations, Rome, 324 pp.

Carpenter KE, Harrison PL, Hodgson G, Alsaffar AH, Alhazeem SH (1997b) The Corals and Coral Reef Fishes of Kuwait. Kuwait Institute for Scientific Research and the Environment Public Authority, 
Kuwait, 166 pp.

Chen IS, Fang LS (2006) A new species of Rhinogobius (Teleostei: Gobiidae) from the Hanjiang basin in Guangdong Province, China. Ichthyological Research 53: 247-253.

Chen IS, Miller PJ (2008) Two new freshwater gobies of genus Rhinogobius (Teleostei: Gobiidae) in southern China, around the northern region of the South China Sea. The Raffles Bulletin of Zoology, Supplement 19: 225-232.

Eschmeyer WN, Fricke R, van der Laan R (2017) Catalog of fishes, version 2017.1. California Academy of Sciences, San Francisco. http://researcharchive.calacademy.org. Accessed on: 2017-06-30.

Fowler HW (1934) Zoological results of the third De Schauensee Siamese Expedition, Part I. Fishes. Proceedings of the Academy of Natural Sciences of Philadelphia 86: 67-163.

Fricke R (1999) Fishes of the Mascarene Islands (Réunion, Mauritius, Rodriguez): an annotated checklist, with descriptions of new species. Theses Zoologicae, Koeltz Scientific Books, Koenigstein,759 $\mathrm{pp}$

Froese R, Pauly D (2017) FishBase. http://www.fishbase.org. Accessed on: 2017-07-29.

Ghanbarifardi M, Malek M (2007) Permanent intertidal fish from the Persian Gulf and Gulf of Oman, Iran. Iranian Journal of Animal Biosystematics 3: 1-14.

Jones D A (1986) A Field Guide of the Sea Shores of Kuwait and the Persian Gulf. University of Kuwait and Blandford Press, Poole, UK, $192 \mathrm{pp}$.

Kottelat M, Whitten AJ, Kartikasari SN, Wirjoatmodjo S (1993) Freshwater Fishes of Western Indonesia and Sulawesi. Periplus Editions, Hong Kong, 221 pp.

Kuronuma K, Abe Y (1972) Fishes of Kuwait. Kuwait Institute for Scientific Research, Safat, Kuwait, 323 pp.

Larson HK (in press) Gobiidae. In: Heemstra P, Heemstra E, Ebert D,
Holleman W, Randall J (Eds) Coastal Fishes of the Western Indian Ocean. South African Institute for Aquatic Biodiversity, Grahamstown.

Larson HK, Murdy EO (2001). Gobiidae, In: Manilo LG, Bogorodsky SV (Eds) FAO Species Identification Guide for Fisheries Purposes: The Living Marine Resources of the Western Central Pacific. Food and Agriculture Organization of the United Nations, Rome, 3578-3609.

Larson HK, Lim KKP (2005) A Guide to the Gobies of Singapore. Singapore Science Center, Singapore, $164 \mathrm{pp}$

Masuda H, Amaoka K, Araga C, Uyeno T, Yoshino T (1984) The fishes of the Japanese Archipelago. Tokai University Press, Tokyo, Japan, 437 pp.

Miller PJ (1988) New species of Corcyrogobius, Thorogobius and Wheelerigobius from west Africa (Teleostei: Gobiidae). Journal of Natural History 22: 1245-1262.

Nelson JS, Grande TC, Wilson MVH (2016) Fishes of the world. John Wiley \& Sons, Hoboken, $651 \mathrm{pp}$.

Patzner RA, Van Tassell JL, Kovačić M, Kapoor BG (2012) The Biology of Gobies. CRC Press: Science Publishers, Boca Raton, Florida, United States, 702 pp.

Rahimian H, Pehpuri A (2006) Intertidal Fishes of Qeshm Island, the Persian Gulf. I. Gobiidae (Pisces: Perciformes). Journal of Science (University of Tehran) 33(4): 69-76.

Senou H, Suzuki T, Shibukawa K, Yano K (2004) A Photographic Guide to the Gobioid Fishes of Japan. Heibonsha, Tokyo, 536 pp.

Thacker C( 2012) Systematics of Butidae and Eleotridae. In: Patzner R, Van Tassell JL, Kovacic M, Kapoor BG (Eds), The Biology of Gobies. CRC Press, Taylor and Francis Group, Science Publishers, Enfield, New Hampshire, 78-85.

Whitley GP (1930) Additions to the check-list of the fishes of New South Wales. (No. 3). Australian Zoologist 6 (pt 2): 117-123. 